\title{
The Fugitives
}

\section{John Malone}

\section{Man and Woman, Circa 1971}

When the doorbell rings, my wife and I are screaming at one another. I have, she claims, boiled a brisket of beef in her brown rice pot, contaminating it irretrievably. She has, there is no doubt about it, invaded my studio while I am painting. My studio is as sacrosanct as her rice pot, any day. So we are both screaming, my face getting purple (she informs me), hers very white.

The doorbell becomes more insistent. Whoever is pushing it can probably hear us screaming, around the corner of the house. The windows to the studio are open.

"Answer the door," I say.

"Answer your own goddamn door," says my wife.

I get up to do so, but usher her out of the studio ahead of me. She is in a mood to slash canvas.

\section{The Revolutionary}

His jeans, if he were to remove them, would surely stand up by themselves.

The rest of his costume follows suit:

Cowboy boots encrusted with mud, the leather cracked and peeling.

A faded peacoat.

Denim shirt.

Beard.

And shoulder length hair.

Even so, by his scraggly teeth and the messianic glint in his eye, I recognize a friend from the past. shoulder.

"I've come from Philadelphia," says Henry, casting a glance over his

\section{Investigators Must Investigate}

"Certainly he was here," I say to them. "But it was weeks ago."

"Did you realize that you were harboring a known criminal?"

When was it, I wonder, that 'alleged' came to mean known'?

But I say merely, "One of the pleasures of living out here in the country is that you never have to see a newspaper." 
"You have a television set," they point out.

"I only use it to watch baseball," I tell them. "I'm a Red Sox fan."

The investigators exchange a look. Painters cannot be baseball fans in their cosmology, it seems.

"Why didn't you report that he'd been here, when you later found out that he was on the run?" One investigator asks most of the questions. The other stares, attempting to intimidate.

"It seemed beside the point. It was days later, and I had no idea where they had gone. I thought it would be a waste of my time and yours."

"You were wrong," says the intimidator. "In this business, there's always some useful piece of information you can pick up. Even if it's not about the accused."

\section{Happy Men Take Pride In Their Accomplishments}

"What in hell were you doing in Philadelphia?" I ask, holding the door wide for my friend to enter.

Henry glances once again over his shoulder. There is nothing to see but fields and trees and sky. My nearest neighbor lives a mile and a half away.

"Don't you read the papers, man?"

He sounds almost piqued. Gently, I explain that I avoid the news.

"Oh, yeah, well, I was blowing up a draft office," says Henry, entering my house, his voice as raucous as of old.

"Really?" I say, flinching at the volume and subduing my dismay. "Do they know you were in on it?"

"Sure, man. The Feds are after me. Isn't that something?"

I am glad for him in a way. A celebrity at last. Once, he had wanted to be an artist, with a capital ' $A$ '. Now that he is a revolutionary (with, $I$ am sure, a capital ' $R$ ') I suppose that it could only be a cause for shame to remain anonymous. It is, after all, the age of publicity.

My wife, drawn no doubt by Henry's stentorian glee (he has always abhored anonymity, it occurs to me, and his voice is a sign of it) has drifted into the hall.

"You mean the F.B.I.?" she says.

\section{A City Girl}

My wife is not happy here in the country.

She consented to move only because it meant that she could grow organic vegetables in the backyard and raise organic chickens in the tool shed.

In all but her ecology, she is a city girl.

She desires noise pollution even as she rejects the other kinds.

The country makes her nervous, it is far too quiet.

At night it is so still you can hear the crickets cheep.

I believe, besides, that she misses women's lib.

\section{A Meeting of Minds}

"Jane, this is Henry Grant." I do not trouble to identify Jane as my wife. It 
is a word she despises. Besides, the matter should be clear to Henry. No mistress would treat a man with the contempt Jane reserves for me.

"Hello, Henry."

"Alias Sonny Berman," says Henry, showing his scraggly teeth in a grin. I recall that Henry never was happy with his own name; too mundane.

"What are they after you for?" asks Jane, eyeing him speculatively.

"He blew up a draft office," I explain.

"Well," she says, "it's nice to meet a man with some guts."

My choices are limited. "You want to stay with us?"

Henry nods, suddenly serious, conspiratorial. "Overnight. I don't think they're even on my trail. I'll get out before dawn."

\section{Investigators Must Speculate}

"How did you meet Henry Grant, alias Sonny Berman?" they ask me.

"The first time I saw him he was wearing brand new loafers."

The investigators sit stony-faced. "Where was that?"

"At school."

"Which school?"

"Andover. It's a prep school." firmed.

The investigators exchange glances, as though a suspicion had been con-

"Why did you mention his loafers?"

"It was by way of observing that people change."

"He was different then?"

"Yes. He wanted to be a writer."

"A writer?" The eyes of the investigators glisten. "What did he write?"

"Stories, poems, plays. Everything. He wrote all the time."

"You read these-stories?"

"Quite a lot of them. I was the art editor of the school literary magazine. He was two years behind me in school but he turned in so many pieces they made him an assistant editor. I got to know him. We became friends."

"Close friends?"

"I suppose. But I graduated, and went on to college. So I only saw him occasionally over the next two years."

"Did he go to the same college?"

"Yes."

"Was he still doing this-this writing-then?"

"Some. But he'd lost the spark. They'd made him editor-in-chief of the magazine at Andover. The exercise of editorial power, and worrying about things like printers' costs and selling advertising space to the local coffee shop took all the romance out of it for him. It stifled him. But then, that's what prep schools are for, to exorcise any strain of creativity from the future leaders of our land. It's their function in society. Andover was always one of the best at the job."

The silent investigator speaks. "Did you ever have sexual relations with the accused?" 
I do not wish to annoy my visitors. But I cannot help myselt. I laugh in their self-important faces.

They look deeply offended.

"I'm sorry," I say. "I shouldn't laugh. Most prep schools also look upon writing and painting as forms of sexual deviation. Anything that isn't directly related to money sounds queer to them."

"You deny that you ever had sexual relations with him?"

"I would never compete with my wife," I say, smiling benignly at them.

\section{The Loving Cup Is Shared}

Henry has arrived in the late afternoon. That means that we can immediately sit down and start drinking.

The liquor cabinet is well stocked.

I offer scotch, vodka, bourbon, etc.

Henry asks if there is any red wine.

Otherwise he will take beer.

It wouldn't do, of course, for a revolutionary to sit around drinking scotch. The President, for Christ's sake, probably drinks scotch.

Unfortunately, though, the only red wine I have in the house is a couple of cases of an excellent 1959 Bordeaux. It is not that I begrudge a good bottle of wine to Henry. But I don't want to insult his revolutionary fervor with a chateau label. I decide to disguise its quality, and decant a bottle into a pitcher. I am sure Henry judges such questions by appearances and not by his palate.

Jane too will take wine.

Usually she drinks vodka martinis.

If I am lucky, she may join the movement and end up behind bars. Probably, knowing my wife, it is just Henry's grotty sex appeal that is working on her. In spite of spindly legs and a cock the size of a toothpick, Henry has an aura of virility. He lolls back in an easy chair with one leg up over the arm, dribbling red wine into his beard.

Jane is entranced.

\section{Investigators Ask Too Many Questions}

"Did Grant have any drugs with him when he was here?" I am asked.

"Not that I know of."

"You're sure about that?"

"Positive."

The pause is brief. "Have you ever taken drugs yourself?"

"I thought you were investigating Henry Grant. If you're investigating me, I'll call my lawyer."

"Why should you need a lawyer?" They ask it very quickly.

"Because I'm dealing with an agency that refers to men as criminals before they've been brought to trial."

The pause is much longer. The investigators stare at me, as though deciding whether or not to get tough. It is the kind of silence affected by actors playing underworld captains in the movies, at those moments when they are contemplating having someone rubbed out. 
"When did you last see Grant, before this visit?" The tone of voice makes it clear that they are, by their lights, being exceedingly patient with me.

"In Paris, five or six years ago."

"Was Grant taking drugs then?"

"I don't believe that's any of your business."

For the first time, the investigators smile. "A grand jury will be called in this case eventually. You realize that we could have you subpoenaed."

I would just as soon the investigators did not smile.

"If I'm called before a grand jury I'll decide at that time whether or not I have a duty to speak. I don't believe I could tell you anything that would be at all important in connection with his alleged activities in Philadelphia."

"Well then, let's put it another way. If in fact Grant is proved to have been involved with blowing up the draft office, would you say that you approved or disapproved of his action?"

"Of course I wouldn't approve. I'm absolutely against violence of any kind. It's stupid, as well as illegal."

The investigators look surprised, as though I had disappointed them. "Then why," I am asked, "are you being so difficult? Why are you protecting your friend?"

"Let's just say that one good turn deserves another."

"So that's it. What did he do for you?"

"He persuaded my wife to run away with him."

There is a silence.

Then, hesitantly, the intimidator speaks. "Are you putting us on, mister?"

\section{Exits}

Jane comes into my room and turns on the overhead light, which I never use. I awake immediately. It is 4:00 A.M.

"I'm leaving," she says.

I blink at the sudden brightness. They have had several hours together. After dinner I returned to my studio, giving them an opportunity to explore further their instant interest in one another. Clearly, they have made the most of their time.

"Where are you going?" I ask.

"With him."

"Yes, Jane. But where? Or aren't I sufficiently trusted?"

"North Africa, eventually."

"You'll like the couscous, I imagine. It's usually made with meat, however."

Jane shrugs, as though food did not matter. I wonder if she will take her rice pot with her.

"It's nice at least to have unchauvinistic sex again," she says. a lesbian."

"Does that mean you fuck him? Besides, I thought you'd decided to become

"I may still. But this seems a more interesting possibility for the moment."

"Just so long as you're happy. But you would have made a splendid lesbian. You have just the right combination of arrogance and querulousness." 
"I'm only going to take a few clothes," Jane says. "Maybe I'll send for some things later."

"All right. Why don't you give Henry a pair of my trousers."

"Why?"

"I'd like to have those jeans of his."

"As a fetish? I always thought you were basically queer."

"I'm interested in them aesthetically, not sexually."

"Okay, I'll ask him."

"Tell him I'd regard it as a fair exchange."

"I'll just bet you would," says Jane.

\section{The Investigators Do Not Comprehend}

"Did Grant discuss his political activities with you?"

"Not his activities. Just his ideas."

"His ideas? Did he give you any idea where he might strike next?"

"It wasn't that kind of conversation. It was an intellectual argument, over drinks and dinner."

"But he did indicate he was for violent action?"

I hesitate.

I phrase my answers carefully. It would distress me to be accused of taking revenge on a man who ran away with my wife.

"He didn't say what he, personally, was planning, or even indicate that he was planning anything. All he did was try to explain to me the reasoning behind the tactics of some of the radical groups. I don't think they all agree with one another."

"What was the, uh, reasoning, he described?"

"Simply that if there was enough violent protest, the repressive actions of the government would become so severe that even the 'silent majority', as some people call it, would become radicalized."

The investigators turn once again to consult one another in silence. "Typical leftist dogma," mutters the intimidator finally.

"Do you agree with this line of reasoning?" I am asked.

"No." I shake my head emphatically. "I told Henry that I thought his belief in the silent majority, while touching, was rather naive. Being by definition gutless-people are only silent because they're afraid to rock the boat-it seemed to me that in a truly repressive society, people would just scrabble around like crazy to get their sons into West Point, or at least the police academy, in the hope that they might end up with a dictator in the family. That's better than my son the dentist any day."

The investigators look down at the pads in their laps, on which they have been scribbling my replies from time to time. They turn to look at one another, and the intimidator holds up an envelope and shrugs.

"There seems to be some discrepancy," I am informed. "You say you don't agree with the radical ideas of your friend. Yet we have information that you are not fully in support of existing forms of government in this country."

"What information?" 
"We don't know who supplied it. But it's in the dossier. The full facts will be on file at the Bureau."

"There are people who would lie about me."

"All right. We'll ask you the question. Do you or don't you believe that radical changes in our governmental forms are needed?"

"I believe that some radical changes are needed, certainly. But violence is not the way to get them."

"How would you go about it, then?"

"I believe in the subversion of art."

"The what?"

"Some kind of subversion," says the intimidator.

"Of art. The subversion of art. Art influences people on a subconscious level, so they aren't as much on the defense against it."

"Art?"

The investigators do not believe in the subversion of art. That is just as well for me, I am certain.

\section{"Art?"}

They take their leave.

They even apologize for taking up so much of my time.

In a more conventional era, they might have regarded me as dangerous, I suppose. But there are, in this time, too goddamn many other radicals in the woodpile to pay any attention to subversion through art, for Christ's sake.

\section{Revolutionary Artifacts}

When I saw Henry in Paris, during the height of his drug period, he showed me a notebook he had written under the influence of mescaline. Although he had, sometime before, given up all ambition of pursuing bourgeois success as a writer, he had apparently retained some drive to express himself. It was a bound notebook, of the kind that French schoolchildren write their lessons in. Henry had filled its pages with a procession of squiggly lines, drawn in ballpoint. They looked like this:

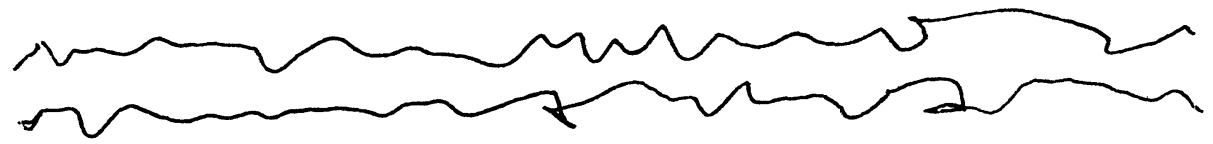

On every third or fourth page there was a stray word or two: a color, as in red, an obscenity, as in fuck, or a god, as in Allah.

In recreating the notebook I cannot claim to have produced an exact representation, of course, but the impact, I hope, will be much the same. This notebook that I have prepared lies open on a small black podium inside a clear plexiglass box some six feet in height. In this box I have also placed a brand new pair of Weejun loafers, size $7 \frac{11}{2} \mathrm{C}$, and Henry's jeans. I have sprayed the jeans with a clear plastic solution that does indeed enable them to stand up by themselves. I call this construction REVOLUTIONARY ARTIFACTS, and it will go on exhibit, together with a number of recent paintings, at the beginning of next month. 
The investigators finally having left, I am taking advantage of the hour or so of remaining daylight to work on the final painting I intend to complete before the coming exhibition. The work is going well.

I may even be able to finish this canvas before evening.

If so, I will break out a bottle of wine from my case of Bordeaux. Just after the investigators left, I took a steak out of the freezer to thaw. With it I believe I shall have some brown rice. Jane did indeed leave her pot behind, and I am fond of brown rice when it is not forced upon me.

I feel very much at peace, very sure of my course as I work steadily away in the afternoon light.

It is very quiet here in the country. 